\title{
H. A. Wallace and the Development of Hybrid Corn
}

\author{
William L. Brown
}

IN THE EARLY 1900s Edward Murray East and George Harrison Shull independently established a sound biological basis for hybrid corn. ${ }^{1}$ Donald F. Jones invented the double cross in 1917, a method of hybrid seed production which made possible the practical application of the earlier discoveries of East and Shull. ${ }^{2}$ But Henry A. Wallace, more than any other single individual, introduced hybrid corn to the American farmer and fervently promoted its adoption. The advantages of hybrid corn over the open-pollinated varieties in use in the early 1900 s were so great that eventually hybrids would have caught the fancy of even the most conservative farmers. Yet the continual, persuasive editorial support in Wallaces' Farmer for this new kind of corn undoubtedly had a major effect on corn belt farmers and helped speed the adoption of hybrids in lowa and adjoining midwestern states.

The first hybrid corn produced was sold commercially by George S. Carter of Clinton, Connecticut, in 1922. Carter was a friend of Dr. Donald F. Jones, corn geneticist and breeder at the Connecticut Experiment Station. Apparently, Jones provided

1. H. K. Hayes, A Professor's Story of Hybrid Corn (Minneapolis, 1963).

2. Donald F. Jones, "Dominance of Linked Factors as a Means of Accounting for Heterosis," Genetics 2 (1917), 446-479 and "The Effects of Inbreeding and Cross-Breeding upon Development," Connecticut Agricultural Experiment Station Bulletin No. 207 (New Haven, 1918). 
Carter with seed of some inbred lines which he crossed and sold to New England dairy farmers. These Connecticut hybrids reportedly performed well, yet Carter remained in the hybrid corn seed business for only a few years. Iowa's Henry A. Wallace was quick to recognize the potential of the new hybrid seed. Writing of the Connecticut hybrids in 1925, he stated, "Corn means so much more to us in the corn belt than it does to the New England farmer that I am hopeful our farmers will be easy to educate to the use of the new seed corn which I believe will be all the rage ten years hence." ${ }^{\prime 3}$

Long before he became interested in hybrid corn, Wallace was fascinated by the study of plants and especially by the grass family. Two individuals can be credited with stimulating his early interest. The first, George Washington Carver, was a botanist on the faculty at lowa State College during the time Wallace's father was professor of dairying there. Carver was a friend of the senior Wallace. At times, Carver took Henry A. with him when collecting specimens and apparently explained to him some of the fundamentals of plant taxonomy. Wallace was a young, pre-school lad at that time, yet he must have learned a great deal from Carver and, characteristically, retained throughout his life most of what he had learned. He later wrote, "I had great affection for him [Carver], simply because he was patient. I suspect he and my mother, between them, were responsible for my acquiring a love of plants at a very early age." ${ }^{4}$ Wallace often referred to Carver as the person who first stimulated his interest in grasses. (Corn is a member of the grass family.) He was proud of his understanding of the complexity of the floral structure of grasses, an understanding that he said was first explained to him by Carver.

The second person who had a considerable influence on Wallace's interest in and attention to corn specifically was the great corn evangelist Perry G. Holden, who, more than anyone else, spread the use of Reid Yellow Dent corn throughout the corn belt. ${ }^{5}$ Holden was lured to Iowa in 1902 by Wallace's

3. Wallaces' Farmer 18 December 1925.

4. Henry A. Wallace, "Reminiscences," Oral History Research Office, Columbia University.

5. In 1846 Robert Reid moved from Ohio to a farm about thirty miles south of Peoria, Illinois, and brought with him seed of a late maturing corn 
grandfather, "Uncle Henry." The elder Wallace, the Iowa Grain Dealers Association, and a few lowa farmers chipped in to help Iowa State College pay Holden four thousand dollars annually, an attractive salary for college professors early in this century. Holden crisscrossed the state in a "Corn Train" provided by the railroads, demonstrating to farmers how to test the germination of seed corn and how to select the best corn to be used for seed. Each year a short course was conducted at Ames at which Holden and his associates demonstrated how to judge corn and how to properly rank a ten-ear sample. ${ }^{6}$ Henry $A$. attended such a short course at lowa State in 1904 when he was sixteen years of age. He later spoke of "sitting hour after hour, day after day, judging Reid corn under the eye of the college corn experts."" Although he questioned the ability of the corn judges to properly rank ears of corn by appearance with respect to the yielding capacity of their progeny, he did feel careful observation of corn permitted a better understanding of the plant: He was greatly impressed by Holden's powers of observation and his ability to stimulate interest on the part of his students. His own interest in corn was intensified through his contact with Holden.

In 1904, Henry A. Wailace, still a teenager, sold his first seed corn-ten bushels for a total of fifty dollars. This corn had been produced on five acres of land located in Des Moines between Cottage Grove and University avenues and between 38th and 39th streets. This seed corn was a cross of open-pollinated varieties and was produced by detasseling the plants of every

called Gordon Hopkins. When Reid planted the Gordon Hopkins corn in the spring of 1847 the resulting stand was very poor. To compensate he replanted the missing hills with a corn known as Little Yellow, an eight to ten row early flint variety grown by the Indians in the northeastern United States for many centuries. The two varieties were crossed accidentally and within the resulting hybrid mixture Robert Reid and his son James practiced selection for many years until eventually a new variety was developed which proved to be one of the highest yielding corns in the central corn belt. It won a prize at the Chicago World's Fair in 1893 and thereafter spread throughout the corn belt under the name of Reid Yellow Dent. Many strains of Reid were developed later by enterprising farmers, some of which have been sources of outstanding inbred lines.

6. Henry A. Wallace and William L. Brown, Corn and lts Early Fathers (East Lansing, MI, 1956), 92-98.

7. Ibid., 95. 
other row in the field. Seed was harvested only from the detasseled plants. Wallace later stated that following the sale of this ten bushels of seed in 1904 he first began to study corn seriously; nine years later he did his first inbreeding of corn. By 1913 he had relocated his experimental plot to twenty acres near Des Moines owned by an uncle, Newton Ashby. ${ }^{8}$

Fifteen years after Wallace began his self-proclaimed "serious-study" of corn, he published a series of articles in Wallaces' Farmer which reveal his understanding of the plant, its history, evolution, variability, and crossing behavior. In March of 1919 he concluded in an article entitled "Some Interesting Corn Hybrids," that the "most popular varieties of dent corn" were not pure strains but hybrids, in differing combinations, of flints, flour corns, and more nearly pure strains of dent. He also criticized the corn shows for emphasizing ranking by appearance at the expense of yield capacity: "The effect of our corn shows has been to reduce the percentage of flint blood in our dent varieties. This has had a tendency to bring about a prettier corn with a slightly heavier yield in long seasons, but with a far larger percentage of soft corn in short seasons. ${ }^{19} \mathrm{His}$ early observation that corn belt dents contained germ plasm of northern flint and southern dents was verified by much later research which proved conclusively that these same races were the parents out of whose crosses and mixtures evolved the yellow dent corn of the United States corn belt. ${ }^{10}$

Wallace's understanding of corn was not confined merely to an objective scientific plan. His investigations also encompassed a unique philosophical, almost spiritual, approach. An article appearing in Wallaces' Farmer in 1921 begins,

Every living thing, whether it be plant, animal, or human being, has an individuality of its own. Some are pleasing some repulsive, but all are interesting to whosoever tries to understand them.

For fifteen years I have tried to understand corn plants until

8. Henry A. Wallace, address delivered to the Pioneer Club, Des Moines, Iowa, 8 September 1962.

9. Wallaces' Farmer, 7 March 1919.

10. Edgar Anderson and William L. Brown, "The History of the Common Maize Varieties of the United States Corn Belt," Agricultural History 26 (1952), 2-8. 


\section{Hybrid Corn/Brown}

now the individuality of corn plants is almost as interesting to me as the personality of animals or human beings. While I hope some day to find a strain of corn which will yield better in the central part of the corn belt than the kinds which we now have, I have spent much of my time with strains of corn which are more interesting than practical. ${ }^{11}$

Continuing, Wallace described some of the plants resulting from his studies, speaking of their "pedigrees" and saying, "I know the stocks from which they came, from which their parents came, the grandparents, and their great-grandparents." He wrote of a favorite variety:

I can walk through the field and tell the Burnett 3 inbred strain every time. There is a faint white stripe in the leaves, and at tasseling time the leaves stay folded tightly around the tassel for a week longer than they should. The third year of inbreeding, every plant of this strain was badly affected with root rot or fusarium . . . . ${ }^{12}$

Obviously, Wallace knew his corn plants well; he knew their strengths, their weaknesses, and their individual characteristics. Also he obviously was reluctant to discard any of his favorite inbred strains even though, as in the case of Burnett 3, the line clearly had more faults than should have been tolerated. Wallace was not alone in this loyalty. Many breeders allow their emotions to influence the selection process and often keep those plants which probably should be discarded. Yet, we should not be critical of this practice. The native Americans of both North and South America, who did so much, to domesticate and improve corn, possessed a depth of feeling about corn that is seldom emulated among Euro-Americans. ${ }^{13}$ Who knows how much the Indians' reverence for corn influenced their attitudes toward it and their capacity to improve it? Who can judge the effect of Wallace's love of plants on his determination to seriously study corn or to become involved in the development and marketing of hybrid seed?

Wallace's corn-breeding philosophy included a strong

11. Wallaces' Farmer, 23 December, 1921.

12. Ibid.

13. William L. Brown, E. G. Anderson, and Roy Tuchawena, Jr., "Observations on Three Varieties of Hopi Maize," American Journal of Botany 39 (1952), 597-609. 
belief in cooperation among experimenters. Many other individuals within the USDA, state experiment stations, and landgrant institutions were also experimenting with hybrid corn in the early 1900s. Wallace maintained close contact with most of those breeders through correspondence and visits. He also exchanged breeding materials and inbred lines with many of the early experimenters. This early-close cooperation between public and private breeders was very important; it has continued to the present and has had a major impact on the progress of corn breeding in the United States. Appropriately, this practice probably started with Wallace who always embraced cooperation and eschewed confrontation and competition. This attitude applied not only to plant breeding but to other nations and peoples as well. ${ }^{14}$.

I $_{\mathrm{N}} 1923 \mathrm{~W}$ Wllace produced his first hybrid to be sold commercially. Copper Cross was a single cross involving a Leaming inbred developed by Professor East and a line out of the variety Bloody Butcher. ${ }^{15}$ The reddish pericarp color of the Bloody Butcher line was expressed in the hybrid, thus the name Copper Cross. George Kurtzweil, then with the Iowa Seed Company, marketed Wallace's hybrid, producing one acre of seed of Copper Cross in 1923 and selling it at a price of one dollar per pound in the spring of 1924. Copper Cross apparently did well in southwestern Iowa but was never produced in significant quantities, due in part, no doubt, to its low-yielding inbred seed parent. ${ }^{16}$

In the mid-1920s Wallace, though fascinated with scientific experimentation, seemed to be uncertain about the best vehicle for the commercial production and marketing of hybrid seed. He once suggested that it was perhaps an occupation for retired farmers. In 1928 he wrote, "How are the scientific and practical seed corn men going to produce a million or more bushels of the right kind of hybrid seed every year?" Did Wallace believe that

14. Wallaces' Farmer, 23 December, 1921.

15. Leaming and Bloody Butcher were two open-pollinated varieties of corn in use in the pre-hybrid era. Leaming was the source of several inbred lines, some of which were used fairly extensively in the early days of hybrids. Neither Bloody Butcher nor lines developed from it were widely used.

16. Iowa Seed Company Catalogue, 1924. 


\section{Hybrid Corn/Brown}

the ultimate market for hybrid seed would be no more than a million or so bushels? He continued, "This year the total supply is perhaps 5,000 bushels, which is a drop in the bucket." 17 Through editorials in Wallaces' Farmer he continued to advance plans for the widescale production of hybrid seed:

Once the experiment stations and seed companies have proved that certain inbreds are the best ones, then certain farmers can specialize in growing inbred seed at perhaps $\$ 10$ a bushel. This is a job which almost any farmer can do, up to the time of picking the seed corn, when some expert help will be needed in order to get proper drying. Other farmers will produce primary crosses, and they will have to be experts, preferably with a college education. They will buy two different inbreds from farmers who grow inbred seed and, after detasseling one sort, will sell the crossed seed to commercial seed men. ${ }^{18}$

Despite the uncertain future structure of the hybrid seed corn industry, Wallace had sufficient faith in the future that he pursued the field. Throughout 1924 and 1925 he produced and marketed small quantities of hybrid seed. In 1924 around one hundred bushels of hybrid seed were produced on approximately three acres. Most of this seed was sold in the spring of 1925 and it performed well. In 1925 almost two hundred bushels of seed were produced and sold in the spring of 1926. That spring Wallace decided to expand the operation and to bring new people and additional finances into the business. He, with a few of his friends, organized the Hi-Bred Corn Company which was incorporated in Iowa on April 20, 1926. ${ }^{19}$ The organizing individuals subscribed to seven thousand dollars capital stock which was paid into the company as needed. Seventy shares of stock were issued at a price of one hundred dollars per share.

The first few years of operation were rocky for the newly formed company. But the directors continued to expand despite temporary setbacks (see Table 1). ${ }^{20}$ During the first year of ex-

17. Wallaces' Farmer, 14 December 1928.

18. Ibid.

- 19. The corporate name was changed later to Pioneer Hi-Bred Corn Company. In 1970 the name became Pioneer Hi-Bred International, Inc. It became a publicly held corporation in 1973.

20. Much of the information on the early history of Hi-Bred is from unpublished sources kindly provided by Mr. Simon Casady. 
The Annals of Iowa

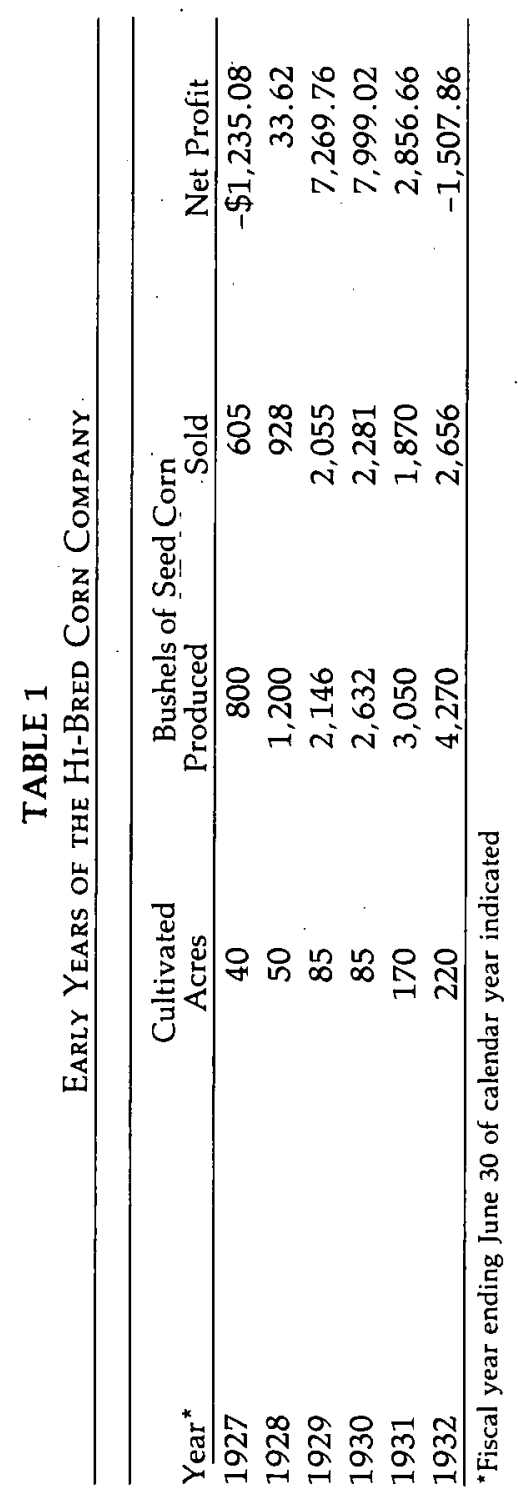


panded operations, the fiscal year ending June 30, 1927, Hi-Bred grew seed on forty acres, sold nearly two hundred bushels less than it produced, and ended the year with a net loss of $\$ 1,235.08$. The following year, seed acreage was increased by 25 percent, seed production increased by 50 percent, and the net profit was $\$ 33.62$. In the third year of operation, 1928-29, production was again increased to a total of eighty-five acres; seed production nearly doubled while sales more than doubled. Even though the company borrowed nearly $\$ 3,000$ for operating expenses and additional building and equipment, it realized a net profit of $\$ 7,269.76$.

In the spring of 1929 an arrangement was made with the Henry Field Seed Company to produce and market Hi-Bred seed on a royalty basis. Hi-Bred furnished the Henry Field company with parent stock which was used to produce the hybrid seed to be sold by Field. A royalty of 15 percent of gross sales was paid to Hi-Bred. In the first year of this arrangement, the Field Seed Company paid $\$ 420$ for parent seed and $\$ 1,592.92$ in royalties.

During its fourth year of operation, Hi-Bred's seed production had more than tripled since its founding-up to 2,632 bushels from 800 the first year. The price of a bushel of hybrid seed corn had also risen to $\$ 10.43$ from the initial $\$ 7.20$ per bushel. With sales reaching 86 percent of producton, net profit to the corporation in the 1929-30 fiscal year was $\$ 7,999.02$.

In the 1930-31 fiscal year the royalty arrangement with the Henry Field was continued and a smilar arrangement was made with Roswell Garst of Coon Rapids, Iowa. ${ }^{21} \mathrm{Hi}$-Bred doubled its' own seed acreage and Garst planted an additional twentythree acres. The original drying plant was totally inadequate to handle the increased amount of seed produced, so the company built a completely new plant, the first such plant designed to handle hybrid seed corn. The new plant and its equipment cost about $\$ 14,000$; additional funds for construction were raised through a 100 percent stock subscription, increasing the capital stock to $\$ 14,000$.

21. Garst later, in partnership with Charles Thomas, formed the Garst and Thomas Hybrid Corn Company to produce and market Pioneer brand hybrid seed corn in the western corn belt. The royalty arrangement with Henry Field was terminated in the mid-1930s while the Garst and Thomas relationship lasted until 1983. 
In the fall of 1930 the old plant was destroyed by fire, resulting in the loss of some parent corn. The new plant was not completed until October of that year, which delayed harvest, increased field loss, and resulted in a low yield of seed. Despite the doubled acreage, only 16 percent more seed was dried, shelled, sized, and bagged that fall. An additional 205 bushels were handled for Garst and Thomas.

The farm economy was entering a serious depression in the early thirties. Corn prices were dropping and farmers were hesitant to pay relatively high prices for seed to produce a crop of decreasing value. In the spring of 1931, for the first time Hi-Bred sales dropped from the previous year. Correspondingly, net profits for the year dropped to less than 40 percent of the previous year's total. Undaunted, Hi-Bred introduced an aggressive promotion plan: Each customer buying two bushels of seed was given a third bushel as a bonus. The company distributed 660 bushels of seed as "bonus" corn.

In 1931, despite the Depression and low farm prices, Wallace's young seed company continued its expansion. Seed acreage was increased from 170 to 220 acres. New additions were made to buildings and equipment, and producerdistributor arrangements were continued with Henry Field and Roswell Garst. The Garst seed acreage increased from twentythree to thirty.

The 1931 growing season was again hot and dry and yields were low. Seed production rose by 40 percent, however, and sales by 42 percent. Another promotion scheme distributed an additional 1,650 bushels to farmers without charge in an effort to demonstrate the advantages of hybrid seed over the openpollinated varieties commonly in use. And an additional quantity of seed was distributed under the terms of a novel delayedpayment plan. Under the terms of this plan, the farmer agreed to pay the retail price if, after harvest, the value of the yield from the hybrid seed was greater than the value of the yield from the farmer's seed by at least twice the regular price of the hybrid seed. These on-farm comparisons between hybrids and open-pollinated varieties in which payment for the seed was dependent upon performance were apparently the first of their kind and did much to encourage the acceptance of hybrid seed.

For the 1931-32 fiscal year, the company showed an 
operating loss of over $\$ 1,500$. The following year, however, $\$ 3,420$ was collected for seed distributed in the spring of 1932 and paid for on the basis of its performance.

The 1932 net loss was the last in the company's history. From that time annual profits rose slowly but steadily, reaching the one million dollar mark in 1954. Ten years later after-tax earnings had almost tripled and they continued to rise steadily thereafter, reaching a high of over 71 million dollars in 1982 on revenues of just over 550 million dollars. Wallace's pioneering effort in developing a commercial seed business had proved to be tremendously successful. It provided financial security to Wallace, his family, and the few original investors and their families. It stimulated the development of a hybrid seed corn industry. which has grown to include hundreds of companies, large and small, which collectively have contributed enormously to agricultural productivity in the United States and the world. Moreover, the success of hybrid corn has stimulated research leading to breeding methodology that has made possible the use of first generation hybrids in other crops-and the process continues.

In 1933, just as his young company was becoming established, Henry A. Wallace was called to Washington to join Franklin D. Roosevelt's cabinet as secretary of agriculture. He resigned as editor of Wallaces' Farmer and turned the management of Hi-Bred over to others. Yet, despite his fulltime involvement in public life, he still found time to give advice and counsel on matters of policy relating to the company and the seed industry. More particularly, he never lost interest in the technical and scientific sides of the business. From the time he left Iowa in 1933 until his death in 1965 he maintained personal contact and carried on extensive correspondence with corporate officers, breeders, and geneticists at Pioneer-raising questions, offering suggestions, and occasionally propounding a new theory relative to breeding behavior or gene action. While he did not shun business, he seemed to prefer to deal with matters of scientific or humanitarian interest: ". . . As a matter of fact, I've not tried to get into business as such. In the corn business, I've tried to outline certain broad policies which I thought 
would result in business success, but have left others the job of business itself." 22

Wallace fully anticipated the problems encountered in introducing a completely new kind of seed corn to conservative farmers in the early 1900s. He also recognized the many risks associated with the production and marketing of hybrid seed corn. He seemed to be concerned particularly about how to deal with carryover inventory. In 1930 he wrote,

The risk element in handling hybrid seed corn is a very substantial item in case all of the seed corn is not sold. The unsold corn has involved in it not only the value of the corn itself but the expense which has been put on it in the way of detasseling, drying, grading, sacking, etc. The first year of our business we suffered a loss largely because we had to carry over about one-fourth of our production, and last year we made a good profit largely because we were able to sell everything we had. As the business becomes larger, this element of risk will, of course, become a more important matter. ${ }^{23}$

In this same address, Wallace broke down the cost per bushel of producing and marketing hybrid seed corn, based on a threeyear average (see Table 2). And he continued to suggest a solution to the carryover problem - a solution he had suggested in previous talks and editorials: "Here again, however, the cost of this item can be cut down materially if a large group of farmers will make an absolute guarantee as to just how much hybrid corn they are willing to buy the following year."

In spite of the problems encountered in persuading farmers to accept hybrid corn, in spite of the difficulties in producing adequate quantities of seed, and in spite of the risks inherent in the hybrid seed corn business, I believe that from the beginning Wallace was confident of the future success of the new kind of corn. In the same 1930 address he spoke of the future and characteristically sounded the call for cooperation in order to achieve the full potential of the newer method of corn breeding:

Hitherto the science of genetics has had practically no influence on practical farming. The newer method of corn breeding will be the first great contribution ....

22. Wallace, "Reminiscences."

23. Henry A. Wallace, "Practical Aspects of the Newer Methods of Corn Breeding," address, 1930. 
TABLE 2

Cost Factors for a Bushel of Hybrid Seed Corn

Research to find better combinations

Maintaining inbreds

$\$ .62$ .30

Primary crossed seed (parent seed)

Detassling

Husking, sorting, shelling, grading, shipping $\quad .61$

Heat and power for drying $\quad .28$

Depreciation on drying plant and equipment $\quad .25$

Bags and string $\quad .24$

Cost of corn itself $\quad .85$

Commission on sales $\quad 1.40$

Advertising, postage, stationery $\quad 1.70$

Risk, waste, shrinkage, misc. $\quad \underline{2.00}$

TOTAL

$\$ 9.00$

SOURCE: Henry A. Wallace, "Practical Aspects of the New Methods of Corn Breeding," address, 1930 .

I sincerely trust that all of us may be able to work together to bring to pass the practical application on a wide scale of the newer method of corn breeding. We shall not have been fully successful until we are able to produce as much corn on forty million acres in the corn belt as we are now producing on fifty million acres. If that transformation is accomplished, the geneticists may well take some pride in the results.

Fortunately, Wallace lived to see hybrid corn adopted on a scale that far exceeded his expectations. While a missionary fervor was required to convince farmers to try the hybrids offered by the emerging hybrid seed corn companies, this was followed by a decade in which the supply of seed never fully met the farmers' requirements. From 1949 to 1965 the production of corn in the United States increased by more than 50 percent while during the same period, the corn acreage declined by about 35 percent. The hopes Wallace expressed in 1930 were far exceeded. Moreover, at least one-half of the yield increase achieved over that period is attributable to genetics. The transformation was accomplished and the geneticists may well take some pride in the results. 
Copyright of Annals of Iowa is the property of State of Iowa, by \& through the State Historical Society of Iowa and its content may not be copied or emailed to multiple sites or posted to a listserv without the copyright holder's express written permission. However, users may print, download, or email articles for individual use. 